Michał Dahl

Nicolaus Copernicus University in Toruń (Poland)

\title{
Integration Processes and Organizations in the Asia-Pacific Region
}

Book Review: Marcin Grabowski, Rywalizacja czy integracja? Procesy i organizacje integracyjne w regionie Azji i Pacyfiku na przełomie XX i XXI wieku. Kraków: Księgarnia Akademicka 2015 (pp. 321). ISBN: 978-83-7638-601-0.

The region of Asia and the Pacific is gaining importance both in political and scientific discourse. The number of publications dedicated to the issue of the role of Asia in contemporary international relations is continuously increasing, which can be justified by the high pace of changes taking place in the region. One of the most significant fields of research for international scholars is the issue of rivalry, but also the creation of institutional links between the countries of the region, as well as competition between the integration concepts presented by individual actors. The issues mentioned above have become the main focus of the research performed by scholars affiliated to the world top universities and research institutes (e.g. Acharya, 2013; Beeson, 2014). Considering Polish science, many scholars drew knowledge and inspiration from the monumental work of Edward Haliżak, the precursor of the multifaceted research on international relations in the Asia-Pacific region (Haliżak, 1999). One of these young scientists is Marcin Grabowski, whose monograph Rywalizacja czy integracja? Procesy i organizacje integracyjne w regionie Azji i Pacyfiku na przełomie XX i XXI wieku perfectly supplements and updates the state of arts about the integration processes and organizations in Asia and the Pacific region at the turn of the $20^{\text {th }}$ and $21^{\text {st }}$ centuries.

The reviewed publication has been divided into four chapters preceded by an extensive introduction. In the introductory part, the author outlines the current state of research on the issue of interest (both in the world and in Polish literature). He also explains the structure of the book, pointing out strengths and weaknesses of the solutions adopted. The Author's attitude towards the methodology of the conducted research deserves the highest recognition. This element, however indispensable in ensuring correctness and transparency 
of the research process, is often overlooked in the work of Polish scientists involved in the study of broadly understood international relations.

Chapter 1 concentrates on theoretical foundations of regional system and integration in the Asia-Pacific region. Elements such as system analysis, levels of analysis, structure of the system, variables and models of the system, have been indicated as the object of the Author's interest. Moreover, he has analyzed theories on regional cooperation, issues of regions and regionalism, as well as factors and stages of international economic integration (p. 18). In the first chapter of the monograph, the Author has undertaken an attempt to analyze possible configurations and polarity of the Asia-Pacific regional system and the role of actors such as: the United States, China, Russia, India, Japan, Australia, ASEAN and the European Union (pp.38-52). The quality of the argument presented in the section, in particular the way in which the possible configurations of the multipolar model have been enumerated and described, demonstrate the author's extensive knowledge and scientific maturity.

The second chapter of the book is dedicated to the transnational dimension of development dynamics of the Asia-Pacific region in a period of 1989-2014. The chapter starts with the presentation of the definition of the area being the subject of the research, as well as the indication (along with the relevant justification) of the definition criteria adopted by the Author for the purposes of the monograph (pp. 71-77). This part is followed by the qualitative and quantitative analysis of factors such as: demography, religious and ethnic diversity, as well as potential and economic diversification of the region. Discussing the above-mentioned factors allowed the author to examine areas of economic integration in the region (pp. 123-138).

The main focus of chapter 3 is Asia-Pacific Economic Cooperation (APEC). The Author put an effort not only to present basic information about the organization's genesis, history and structure, but also referred to the demands of reform and indicated the most significant challenges that APEC is facing nowadays (e.g. negotiation and implementation of the Trans-Pacific Strategic Partnership Agreement - TPP). A valuable element of the chapter is its last subsection, being an assessment of APEC's current activities and future development perspectives (pp. 188-196).

The structure of chapter 4 resembles the structure of chapter 3, but its main focus became integration of the East Asia region, especially activity of the Association of South East Asian Nations. Noteworthy is the way Author describes the so-called ASEAN Community pillars, i.e. the ASEAN Economic Community (AEC), the ASEAN Political-Security Community (APSC), and the ASEAN Socio-Cultural Community (ASCC). He not only characterized them, but also referred to their importance in the context of creating the ASEAN Community until 2020 (pp.230-244). The determination of possible configurations of economic agreements in the Asia-Pacific region (p. 262), made in the context of the analysis of the implications of the Eastern Asia Summit (EAS), is an interesting attempt to explain the complexed interrelations (in this case commercial dependencies) between countries of the region. Questions asked 
by the Author, as well as the way of answering them, directly corresponds with the motive of the monograph, which are listed in the title as "competition" and "integration".

In the summary part the Author of the work once again refers to the key issues raised in the monograph, recognizing that "the institutional architecture of the Asia-Pacific region [...] should be considered weak and highly secondary in a relation to the basic actors operating in the regional system..." (p. 275). In conclusion the Author stated that finding the unambiguous resolution of the dilemma mentioned repeatedly throughout the book rivalry or integration - is not easy (p. 284). He noted that despite the existence of multiple integration initiatives, there is a multi-level competition in the Asia-Pacific region. This dichotomy makes "Asia-Pacific system a hybrid, combining both currents in a way that allows the region to last, or even further develop, and its current institutional infrastructure is matched to the possibilities existing in this system" (p. 285).

In his monograph Rywalizacja czy integracja? Procesy i organizacje integracyjne w regionie Azji i Pacyfiku na przełomie XX i XXI wieku Marcin Grabowski presents well-designed and interpreted analysis, based on solid methodological foundations and taking into account the systemic approach and the theories of regional integration. Structure of the book is logical and compact, whereas the division on chapters and subsections is clear. A distinctive element of the publication are extensive references to literature and original documents, reports, manifestos, agreements, statistics and journals. The technical side of the work deserves special recognition as a painstaking process undertaken by the Author. On the other hand, some readers might feel overwhelmed by the number of details presented out of the main text. Precise familiarity with the content of footnotes sometimes taking more than half of the book's pages (e.g.p. 89), at times distorts the logic of the argument presented by the Author. Those extensive footnotes, together with some minor structural errors (e.g. "w stosunkach z każdym tych krajów" p. 281), are the only weaknesses that can be found in the reviewed work. Those drawbacks, however, in no case affect the unambiguously positive reception of the monograph.

Taking everything into consideration, the book is undoubtedly worth reading. The reviewed work is a valuable and current source of information on integration processes and organizations in the Asia-Pacific region. The scope of the research, as well as the quality of interpretation of the collected data, make the work of Marcin Grabowski a model for publications prepared by young Polish - and not only Polish - scholars.

\section{References}

Acharya A. (2013). Constructing a Security Community in Southeast Asia: ASEAN and the Problem of Regional Order. Oxfordshire-New York: Routledge.

Beeson M. (2014). Reginalism and Globalization in East Asia. Politics, Security and Economic Development.

New York: Palgrave Macmillan. 
Grabowski M. (2015). Rywalizacja czy integracja? Procesy i organizacje integracyjne w regionie Azji i Pacyfiku na przełomie XX i XXI wieku. Kraków: Księgarnia Akademicka.

Haliżak E. (1999). Stosunki międzynarodowe w regionie Azji i Pacyfiku. Warszawa: Wydawnictwo Naukowe „Scholar”.

\section{Author}

\section{Michał Dahl, MA}

Nicolaus Copernicus University in Toruń, Faculty of Political Science and International Studies.

Contact details: ul. Batorego 39L, 87-100 Toruń, Poland; e-mail: dahl.michal@gmail.com 